\title{
Theoretical Study of Policy in Tax Payment
}

\author{
Cipto Dwiariyanto, Mukarto Siswoyo*, Endang Sutrisno \\ Universitas Swadaya Gunung Jati \\ Cirebon, Indonesia \\ *muksis2000@gmail.com
}

\begin{abstract}
Regulatory policies in Law Number 6 of 1983 Article 1 Paragraph 1 as amended by Law Number 28 of 2007 Article 1 Paragraph 1 and taxes have a very important role in the life of every country. The revenue taken from taxation is used by the state and institutions for various kinds of infrastructure development in the country. The government uses tax funds to finance social welfare and public services such as: education, health, retired, public transportation and remote area development. Population growth in Indonesia from year to year get increased. Most of the population of Indonesia is young generations and they work with Non-Taxable Income (PTKP). In the sense of tax, there is a mandatory component that must be done by individuals, namely the mandatory contribution of each citizen.
\end{abstract}

Keywords: social welfare, public service, tax payment

\section{INTRODUCTION}

Every taxpayer who has a Taxpayer Identification Number (NPWP) and has a job, is subject to income tax in Article 21. It explains taxes on income in the form of salaries, honorarium, benefits, and other payments by name and in any form in relation to work or position, services and activities carried out by individuals who are domestic tax subjects. Every year, taxpayers who already have a job and income are required to deposit tax no later than the 10th of the following month after the tax period ends and must report the tax no later than 20 days after the tax period ends. In reporting the Notification Letter (SPT), there are 3 statuses: nil, underpayment, or overpayment.

Taxes are considered as nil if the tax withheld is in accordance with the tax borne. Taxes are considered to be overpaid if the tax withheld is greater than the tax borne. Taxes are considered underpaid if the taxes paid are less than the taxes borne. In the case of insufficient, taxpayers can pay the underpayment to the Post Office, but starting in 2012 the Tax Office began to launch a system called $e$-Billing.

Since the launch of the electronic tax payment system, the Tax Office did not require underpaid taxpayers to use the system directly. So that taxpayers are still unfamiliar with the system. In 2016, underpaid taxpayers were required to make payments using $e$-Billing. The lack of knowledge about the use of e-Billing and the system's dependence on internet connections must always be stable. These constraints have a significant impact on the use of $e$-Billing systems. This study is intended to understand tax payment policies, regarding the enactment of the Minister of Finance Regulation Number 32 /
PMK. 05/2014 on the Electronic State Revenue System. Taxpayers are expected to be able to carry out their obligations efficiently, a fast process without any obstacles in administrative procedures. Awareness and compliance with legal provisions are absolute prerequisites to support the achievement of the objectives of the tax payment policy. Law and policy will reinforce the purpose of state and it can also be done through other positive norms, like Law Number 41 of 2004, the government introduced the concept of Productive Waqf. In this concept, various schemes that encourage waqf assets to be productive value are offered so that they can support them economically and assist in improving society welfare. The application of this waqf concept happens in Cirebon City through stakeholders, like the Office of Ministry of Religious Affairs Cirebon City, Indonesian Waqf Board of Cirebon City, ATR/BPN Cirebon City and other related institutions that determine the success of this concept [1].

\section{METHODS}

This uses descriptive qualitative research methods relating to tax payment policies through e-billing. This is quite reasonable because this research focuses on efforts to explore, discover and explain about the factors that influence the implementation of tax payment policies using e-billing. This research also examines the obstacles in implementing the policy. This research is descriptive research that uses data in the form of words and pictures obtained from transcript of interviews, field notes, pictures, videos, personal documents, official documents, memos and other documents [2].

\section{RESULTS AND DISCUSSION}

This study emphasizes a renewal of the system in the process of administering excellent service to the community. It is hoped that a central point can be used as a guideline for the realization of a mutually beneficial relationship in the service process between government institutions and the community. There are several potential problems that cause difficulties or disadvantages for an organization to improve $e$-Billing services as follows: Software is still easy and is often hacked or hijacked by unscrupulous persons.

If the internet or electricity around are in trouble, the system will also have problems, because this system depends on the internet network and also the electric totally, if the master software is affected by a virus, all data will be lost and it is difficult to find the history of its back up and Fake Application. Nowadays the Directorate General of Taxes has 
made an Android-based e-Filing application. In installing the application, there has been a disclaimer that the Directorate General of Taxes is not responsible for misuse of data or information belonging to the Taxpayer as a result of using applications that are not official applications provided by the Directorate General of Taxes.

The Tax Office of Pratama Cirebon was established in 1948 under the name of the Financial Inspection Office. Then it undergoes a period of change, like:

- The period of 1948-1965, the name of The Tax Office of Pratama Cirebon is the Financial Inspection Office.

- The period of 1969-1989, the name of the Financial Inspection Office is changed into the Tax Inspection Office of Cirebon.

- The period 1989 to August 14 2007, the name of the Tax Inspection Office of Cirebon was changed into the Tax Service Office of Cirebon.

- The period 14 August 2007 until Now, the Tax Service Office of Cirebon was changed into the Tax Office of Pratama Cirebon through the Decree of the Directorate General of Tax Number: KEP-112/PJ/2007 dated August 9, 2007 on the Implementation of Organizations, Work Procedures and when the operation of the Tax Office of Pratama Cirebon and Service Offices, Counseling and Taxation Consultation in the scope of the Regional Office of the DJP Banten, the Regional Office of the DJP West Java I and the Regional Office of West Java I starts.

- The Head of Office is the highest position in Tax Office of Pratama Cirebon and it oversees the Head of General Subdivision, Head of KP2KP Sumber, and Head of Section. The head of Subdivision, Head of KP2KP Sumber, and Head of Section oversee the implementers. There are certain positions in Tax Office of Pratama Cirebon such as Account Representative. It is responsible to the Head of the Waskon Section and the Functional Tax Auditor who reports to the Head of Office directly. Sub Division, Sections and Functional Groups of Tax Auditors have a brief description of the task as follows:

1. Internal and Compliance Subdivision has the task of carrying out personnel, financial, administrative, and household matters.

2. Service Section has the task of receiving Submission of Notification Letter, counter service, issuing tax law products, administering tax documents, receiving and managing Notification Letter, and receiving other letters, NPWP registration, SSB validation, printing SPPT and receiving applications related to $\mathrm{PBB}$ problem.

3. Extensification Section has the task of inventorying Taxpayer Data and Tax Objects, making fiscal monographs, measuring and assessing PBB objects, implementing additional Taxpayers.
4. Supervision and Consultation Section has the task of carrying out supervision of taxpayer compliance, guidance/appeal to taxpayers and taxation technical consultation, compilation of taxpayer profiles, analysis of taxpayer performance, reconciliation of taxpayer data in order to carry out intensification, and evaluation of objection/appeal results.

5. The Billing Section has the task of carrying out administration of tax receivables, delays and installments of tax arrears, active billing, proposals for eliminating tax receivables, as well as storing collection documents.

6. The Data and Information Processing Section has the task of carrying out data collection and processing, recording the Notification Letter, STTS, providing computer technical support services, monitoring tax revenue realization, e-SPT and e-Filing applications, and preparing performance reports.

7. The Audit Section has the task of compiling an audit plan, issuance and distribution of Tax Examination Orders and other tax audit administrations.

8. Functional Group has the task of carrying out the examination in order to test 7ompliance with tax obligations to taxpayers based on laws and regulations.

9. The Tax Counseling and Consultation Service Office (KP2KP) has the task of carrying out counseling and serving counseling requests from taxpayers, receiving Notification reports, other letters and NPWP registration to be forwarded to the KPP.

\section{A. Understanding Public Policy}

According policy in general indicates the behavior of an actor (for example an official, a group, or a government agency) or a number of actors in a particular field of activity. Understanding this policy can be used and it is relatively adequate for the discussion, but it becomes inadequate for more scientific and systematic discussions concerning public policy analysis. Therefore, we need more appropriate public policy boundaries or concepts [2].

According to public policy is a tool to achieve a goal related to the administration of public values. The publicity values as the purpose of the policy have various forms. Society need ideal values such as justice, equality, and luck [3]. For related efforts to realize an effective law system it is necessary to reorganize the legal institution, which is supported by qualified human resources and culture and a growing awareness of the community about law [4].

Policy implementation is the stage of the policy process after the enactment of the law. Implementation has the meaning of implementing a law whereby various actors, organizations, procedures and techniques work together to carry out policies in an effort to achieve policy or program objectives. In the end, there is a close relationship between law and policy, because policy issues at the implementation level will cover various aspects. Law enforcement refers to implementing the textual of legal norms in the social realities of society. The content of 
the substance of the norm is hoped to be clarified through legal behavior so that questions about legal awareness, legal compliance, legal feelings, and legal attitude will be more prominent [5].

The model they offer has six bids and has six variables that form the link between policy and performance. These variables are: basic measures and policy objectives, policy sources, communication between organizations and implementing activities, characteristics of implementing agencies, economic, social and political conditions and tendencies of implementers.

There are four factors or variables that influence the success or failure of policy implementation, like communication, resources, dispotions, and bureaucratic structural factors. Public policy information needs to be conveyed to policy actors so that policy actors can know, understand, what is the content, goals, direction of the target group. In carrying out policy, communication has several dimensions, including the dimensions of transmission, clarity, and consistency. Each variable influences each other for example bureaucracy structure can influence the implementation of policy indirectly or influences disposition variable directly. Communication also can influence the policy through bureaucracy structure, resource and disposition indirectly or influence implementation of policy directly [6].

- The dimension of transformation requires that the policy can be informed to the implementers, the target group and other parties related to the policy.

- The clarity dimension requires that the policies transmitted to the implementers and other parties know what are the aims and objectives of the policies.

- The consistent dimension requires that policies must always be consistent in accordance with policies.

Resources include human resources, financial resources, equipment resources (buildings, equipment, land, and other instruments needed in implementing the policy), and information resources and authority. The successful implementation of policy is not only determined by how far the actors know what must be done, but also it is determined by political will of the actors who has strong disposition to the policy being implemented.

Policy implementation may not be effective due to inefficient bureaucratic structures. This bureaucratic structure includes some aspects such as organizational structure, division of authority, relations between organizational units, and relations of organizations with outside organizations. To get a mandate to implement a policy effectively, the organizational structure must be arranged in accordance with the objectives and complexity of the policy. The approach in the organizational structure is usually done from the top and down, or the process starts from superiors to subordinate executors, or the opposite from the bottom up, or the process starts from subordinate to superior executors.

After the approach in the organization, then the organizational structure is formed. The shape of the structure is also influenced by the objectives of a policy or program that is implemented and the complexity of the policy also affects the organizational structure of the implementer. So the complexity of a policy or program that will be implemented is appropriate if the structure is also complex which can accommodate the various organizations involved in implementation. Conversely, when the policy or program implemented is simple, the organizational structure that implements the policy is also simple. And facilities that consist of infrastructures are important factor to measure the success of a government program that becomes s shared responsibility to carry it out [7].

\section{CONCLUSION}

Understanding of public policy becomes very important considering policy issues can involve the interests of the wider community if it is related to tax payments that must be understood in the form of the State's alignments to build social welfare. The indicators of successful public policy in the understanding of the program must be addressed with a sustainable meaning so that the program offered can achieve its objectives, as well as policies in the field of tax payments.

\section{REFERENCES}

[1] M. Siswoyo, I. Permana,and A. Arofah, "Productive WAQF: Potentia Resources for Society Welfare: Case Study in Cirebon City, West Java”, Asian Journal of Social Sciences \& Humanities, vol. 8, no. 3, p. 28 2019

[2] J. Ahmad, Metode Penelitian Administrasi Publik Teori dan Aplikasi. Yogyakarta: Gava Media, 2015

[3] Winarno, Kebijakan Publik:Teori, Proses, Dan Studi Kasus. Jakrat: Cempaka Putih. CAPS (Center of Academic Publishing Service), 2014.

[4] E.A. Purwanto, Implementasi Kebijakan Publik Konsep dan Aplikasinya di Indonesia. Yogyakarta: Gava Media, 2012

[5] E. Sutrisno, "the Legal Problem of Using Non Environmentally Friendly Fishing Gear in the Fisher Community of Indonesia," EurAsian Journal of BioSciences, vol. 13, no. 2, 2019.

[6] E. Sutrisno, "The Study of River Pollution Related To Domestic Waste in the Perspective of Community Legal Culture", South East Asia Journal Of Contemporary Business, Economics And Law, vol. 12, 2017.

[7] S. Khumayah and M, Siswoyo, "Male Family Planning Program as an Effort to Suppress Population Growth in Indonesia", Asian Journal of Social Sciences \& Humanities, vol. 8, no. 3, 2019. 